Огляди літератури, оригінальні дослідження, погляд на проблему

УДК 616.89-008-053.2+616.12-089-053.2-092

DOI 10.11603/1811-2471.2016.v0.i4.7088

\title{
ПРОГРАМА ПСИХОЛОГІЧНОЇ ДОПОМОГИ ПІДЛІТКАМ ІЗ ВРОДЖЕНИМИ ВАДАМИ СЕРЦЯ
}

\section{ду «Науково-практичний медичний чентр дитячої кардіолозії та кардіохірураї̈ МОз Українир м. Киів}

РЕЗЮМЕ. У статті представлена схема та принципи психологічної допомоги підліткам із вродженими вадами серця (ВВС). У дослідженні взяли участь 25 підлітків з ВВС віком 13-15 років, з підвищеним у них рівнем тривоги, ознаками депресії та слабким почуттям когеренції. Психокорекційні заходи охоплювали від 5 до 10 індивідуальних консультацій з підлітками та окремо з батьками. Психокорекційна програма складалась з елементів раціональної та когнітивно-біхевіоральної терапії, включала розбір складних життєвих та клінічних ситуацій (кейсів), аутогенне тренування та елементи кардіо- та психоосвіти. Програма виявилась ефективною у всіх підлітків з ВВС - вдалося нормалізувати рівень тривожності та у переважної більшості ліквідувати ознаки депресії. Крім того, протягом півроку вдалось сприяти розвитку та підвищенню почуття когеренції серед підлітків з ВВС.

КлючОВІ СЛОВА: підлітки, вроджені вади серця, психологічна допомога.

Вступ. Завдяки стрімкому прогресу в медицині 90 \% новонароджених з вродженими вадами серця (ВВС) досягають дорослого віку [1], тому все більше науковців приділяють увагу дослідженню якості життя пацієнтів з ВВС [2-4] з акцентом на фізичну та психосоціальну реабілітацію хворих [5].

Серед психосоціальних проблем та викликів, з якими стикаються діти та підлітки з ВВС, дослідники виділяють наступні: 1) переживання через зовнішній вигляд (ціанотичні губи та кінчики пальців, маленька статура, хірургічні шрами) [6, 7]; 2) фізичні обмеження (задишка, почуття зниження життєвих сил, витривалості, швидкості рухів та необхідність часто відпочивати) [6, 7]; 3) психоемоційні проблеми (тривога, депресія, занижена самооцінка, неадекватний копінг та відчуття «іншості / ненормальності») [8-10]; 4) соціальні проблеми (дискримінація, булінг, обмеженість у відвідуванні позашкільних заходів [9]; 5) більше ніж у половини підлітків відсутність знань щодо власного серцевого діагнозу та плану лікування [11].

При дослідженні копінгу та витривалості/ стійкості (resilience) у підлітків з ВВС корейські вчені виявили, що стратегія, орієнтована на вирішення завдань, які, насамперед, включали освітні заходи щодо ВВС, напряму була пов'язана зі здатністю підлітка краще протистояти стресу та швидко відновлюватись [12]. Окрім того, виявлено, що почуття когеренції (зв'язності, узгодженості а6о логічної послідовності), the sense of coherence $\epsilon$ позитивним предиктором в фізичному, емоційному, соціальному та шкільному функціонуванні підлітків з ВВС [13].

Почуття когеренції вперше було висунуто в 80-х роках в рамках салютогенетичної парадигми, запропонованої ізраїльським соціологом А. Антоновським [14], який вкладав в цю концеп- цію ідею, що сам по собі стрес не завжди $є$ патогенним, а в деяких ситуаціях викликає таку напругу організму, що здатна провокувати нові адаптивні реакції. Є. Н. Осин у своїй статті «Почуття зв'язності як показник психологічного здоров'я та його діагностика» наводить три компоненти за А. Антоновським, а саме: здатність особистості збагнути стресову ситуацію, керувати ситуацією та цілком її усвідомлювати [15]. Слід також зазначити, що почуття когеренції багато в чому схоже з поняттям життєстійкості, введеним С. Кобейса та С. Мадді [16], адже в обох випадках мова йде про особистісні предиктори або копінг-механізми, які дозволяють не тільки протистояти негативним ефектам стресорів, але й рухатися до психічного та соматичного благополуччя $[17,18]$

Мета дослідження. Враховуючи висвітлені вище психосоціальні проблеми підлітків з ВВС та психологічні предиктори якості життя, метою дослідження була розробка та оцінка ефективності програми психологічної допомоги підліткам з ВВС.

Матеріал і методи дослідження. Дослідження було проведено протягом 2015 - 2016 років на базі дУ «Науково-практичний медичний центр дитячої кардіології та кардіохірургії МОЗ України». 3 дотриманням принципів медичної етики та деонтології до участі у програмі з психологічної допомоги з 60 дітей були відібрані 25 підлітків з ВВС віком 13 - 15 років, з них 15 (60 \%) хлопців; з підвищеним у них рівнем тривоги, ознаками депресії та слабким почуттям когеренції.

Діагнози ВВС включали наступні вади: дефект міжпередсердної перегородки (7 (28 \%) осіб), дефект міжшлуночкової перегородки (5 (20\%) осіб), вроджені вади аортального клапана (8 (32 \%) осіб), тетрада Фалло (3 (12 \%) осіб), єдиний шлуночок (1 (4 \%) особа), коарктація аорти (1 (4\%) особи).

Психокорекційні заходи охоплювали від 5 до 10 індивідуальних консультацій з підлітками та 
Огляди літератури, оригінальні дослідження, погляд на проблему

окремо з батьками. Психокорекційна програма складалась з елементів раціональної та когнітивно-біхевіоральної терапії, включала розбір складних життєвих та клінічних ситуацій (кейсів), аутогенне тренування та елементи кардіо- та психоосвіти.

Батькам додатково була надана можливість взяти участь в круглих столах за участю інших батьків та запрошених медичних працівників. Також в рамках психокорекційної програми був розроблений спеціальний паспорт здоров'я пацієнта з ВВС, який заповнювали самостійно підлітки, підлітки разом кардіологом та підлітки разом 3 психологом. Такий паспорт включав, наприклад, розділи про діагноз, схематичне зображення анатомії ВВС, назви та особливості проведених операцій, медикаменти, які необхідно приймати пожиттєво та в кризових ситуаціях, дозволене фізичне навантаження та профілактика сколіозу, контрацепція, планування кар'єрних/професійних можливостей, теми пройдених тренінгів 3 психологом та інше.

Оцінювання ефективності психокорекційних заходів відбувалось за динамікою показників тривожності та депресії на початку стаціонарного лікування та через півроку на плановому амбулаторному прийомі у кардіолога, для цього ми застосовували Госпітальну шкалу тривоги та депреciï (Hospital Anxiety and Depression Scale (HADS)) [19] та методику для дослідження почуття когеренції - «Шкала відчуття зв'язності А. Антоновського» - The sense of coherence (SOC-29) $[15,20]$.

Математичну обробку результатів проводили з використанням пакета програм SPSS (Statistical Package for Social Science) версії 12.0.2 та програми Excel. Для виявлення розбіжностей під час підрахунку динамічних змін за шкалами ми застосовували Т-критерій Вілкоксона.

Результати й обговорення. За результатами психодіагностичного етапу на початку стаціонар- ного лікування, клінічні ознаки тривожності були виявлені у 11 (44\%) підлітків з ВВС та у 14 (56\%) осіб - субклінічні ознаки тривожності; клінічні ознаки депресії були виявлені у 3 (12\%) підлітків, у інших осіб був виявлений субклінічний рівень прояву депресивних ознак відповідно. Середні показники підлітків з BBC за методикою HADS та SOC-29 на початку та через півроку представлені в таблиці 1.

Статистична обробка результатів імплементованої програми медико-психологічної допомоги за показниками психоемоційного стану та почуттям когеренції підкреслили ефективність розробленої програми. У всіх підлітків з ВВС вдалося нормалізувати рівень тривожності, у переважної більшості - ліквідувати ознаки депресії. Крім того, протягом півроку вдалось сприяти розвитку та підвищенню почуття когеренції серед підлітків 3 ВВС. Детальна схема розробленої програми медико-психологічної допомоги підліткам з ВВС представлена в таблиці 2.

Структуру зовнішніх впливів на ресурс підлітка з ВВС можна зобразити у вигляді схеми, представленої на рисунку 1.

Підсумовуючи теоретичний та практичний досвід дослідження можна говорити про те, що можливість збагнути підлітком діагноз ВВС може реалізуватись у ситуації, коли лікуючий лікар дає пацієнту зрозумілі, структуровані та впорядковані дані щодо захворювання, які за правильної стратегії лікування можливо буде передбачити, на противагу інформації хаотичній, випадковій, неструктурованій та непередбачуваній. Підліток 3 BBC, який має можливість збагнути та опрацювати отриману інформацію, не обов'язково буде намагатись зрозуміти всі деталі свого стану, однак буде мати стійке відчуття, що в принципі, при бажанні, він може вникнути та осягнути представлену лікарем інформацію та знайти в ній відповідний сенс.

Таблиця 1. Результати SOC-29 та HADS у підлітків з BBC, які брали участь у програмі з психологічної допомоги на початку стаціонарного лікування та через півроку*

\begin{tabular}{|c|c|c|c|}
\hline Шкала & $\begin{array}{c}\text { Підлітки з ВВС на початку } \\
\text { стаціонарного лікування } \\
\text { ( } \mathrm{n}=25) \\
\text { M (SD), } \\
\text { Median } \\
\text { (min.-max.) }\end{array}$ & $\begin{array}{c}\text { Підлітки з ВВС через півроку, на } \\
\text { амбулаторному прийомі } \\
(\mathrm{n}=25) \\
\text { M (SD) } \\
\text { Median } \\
\text { (min.-max.) }\end{array}$ & $\begin{array}{c}\text { Р (Т-критерій } \\
\text { Вілкоксона) }\end{array}$ \\
\hline $\begin{array}{l}\text { Почуття когеренції } \\
\text { (sense of coherense) }\end{array}$ & $\begin{array}{l}74.52(5.67) \\
75(65-85)\end{array}$ & $\begin{array}{c}84.60(8.77) \\
80(75-100)\end{array}$ & $<.01$ \\
\hline Тривога & $\begin{array}{c}10.84(2.30) \\
10(8-16)\end{array}$ & $\begin{array}{l}5.24(1.33) \\
5(3-7)\end{array}$ & $<.01$ \\
\hline Депресія & $\begin{array}{c}8.96(1.57) \\
8(8-14)\end{array}$ & $\begin{array}{l}5.04(2.47) \\
5(0-9)\end{array}$ & $<.01$ \\
\hline
\end{tabular}

Примітка. *Результати подані в форматі середнє арифметичне - M та стандартне відхилення - SD, медіана, мінімальний та максимальний показники. 
Огляди літератури, оригінальні дослідження, погляд на проблему

Таблиця 2. Схема програми медико-психологічної допомоги підліткам з ВВС

\begin{tabular}{|c|c|c|c|}
\hline Назва заходу & Учасники & Мета & Інструкція проведення \\
\hline $\begin{array}{l}\text { Кардіоосвітні консультації на теми: } \\
\text { Анатомія вади та тактика лікування } \\
\text { Критичні ситуації та способи реагування } \\
\text { Фізкультура та принципи здорового спо- } \\
\text { собу життя (профілактика едокардиту, } \\
\text { контрацепція) }\end{array}$ & $\begin{array}{l}\text { Кардіолог та } \\
\text { підліток з ВВС }\end{array}$ & \begin{tabular}{|l|} 
Роз'яснення кардіологом \\
медичних термінів, на- \\
лагодження довірливого \\
діалогу та делегування \\
повноважень про збере- \\
ження здоров'я підлітку \\
\end{tabular} & $\begin{array}{l}\text { Під час консультацій } \\
\text { заповнюється } \\
\text { індивідуальний паспорт } \\
\text { здоров'я }\end{array}$ \\
\hline $\begin{array}{l}\text { Психокорекційні консультації на теми: } \\
\text { Як протистояти стресу та почуватися } \\
\text { радісним і спокійним або як правильно } \\
\text { налаштуватись на операцію та період } \\
\text { госпіталізації? } \\
\text { Як покращити спілкування та розуміння } \\
\text { з батьками та однолітками? (Розбір } \\
\text { конфліктних ситуацій та ефективних } \\
\text { способів їх вирішення) } \\
\text { Як мотивувати себе вчитись, будувати } \\
\text { життєву стратегію та плани на майбутнє? }\end{array}$ & \begin{tabular}{|l|} 
Психолог та \\
підліток з ВВС
\end{tabular} & \begin{tabular}{|l|} 
Вивчення підлітком \\
ефективних копінг- \\
стратегій та методів са- \\
модопомоги при тривож- \\
но/ депресивних станах; \\
підвищення у піділтка \\
почуття когеренції
\end{tabular} & $\begin{array}{l}\text { За бажанням підлітка } \\
\text { індивідуальні консультації } \\
\text { або у групі, з елементами КБТ, } \\
\text { раціональної та арт-терапії. } \\
\text { Під час роботи заповнюється } \\
\text { паспорт здоров'я, перегля- } \\
\text { даються короткі мотивуючі } \\
\text { відеофільми та проробляють- } \\
\text { ся аутотренувальні вправи }\end{array}$ \\
\hline $\begin{array}{l}\text { Психоосвітні консультації на теми: } \\
\text { Як збалансовано виховувати підлітка, } \\
\text { уникаючи гіперопіки? (Розбір конфлікт- } \\
\text { них ситуацій та адекватних способів їх } \\
\text { вирішення). } \\
\text { Як підготувати підлітка до хворобливих } \\
\text { лікувально-діагностичних процедур? } \\
\text { Як справлятися з батьківськми стресами, } \\
\text { тривогою, апатією? }\end{array}$ & \begin{tabular}{|l|} 
Психолог та \\
батьки підлітка \\
з ВВС
\end{tabular} & $\begin{array}{l}\text { Покращення стосунків } \\
\text { між підлітком та бать- } \\
\text { ками, нормалізація } \\
\text { психоемоційного стану } \\
\text { батьків }\end{array}$ & $\begin{array}{l}\text { Проведення індивідуальних } \\
\text { консультацій, круглих столів, } \\
\text { лекцій, перегляд коротких } \\
\text { відеофільмів }\end{array}$ \\
\hline
\end{tabular}

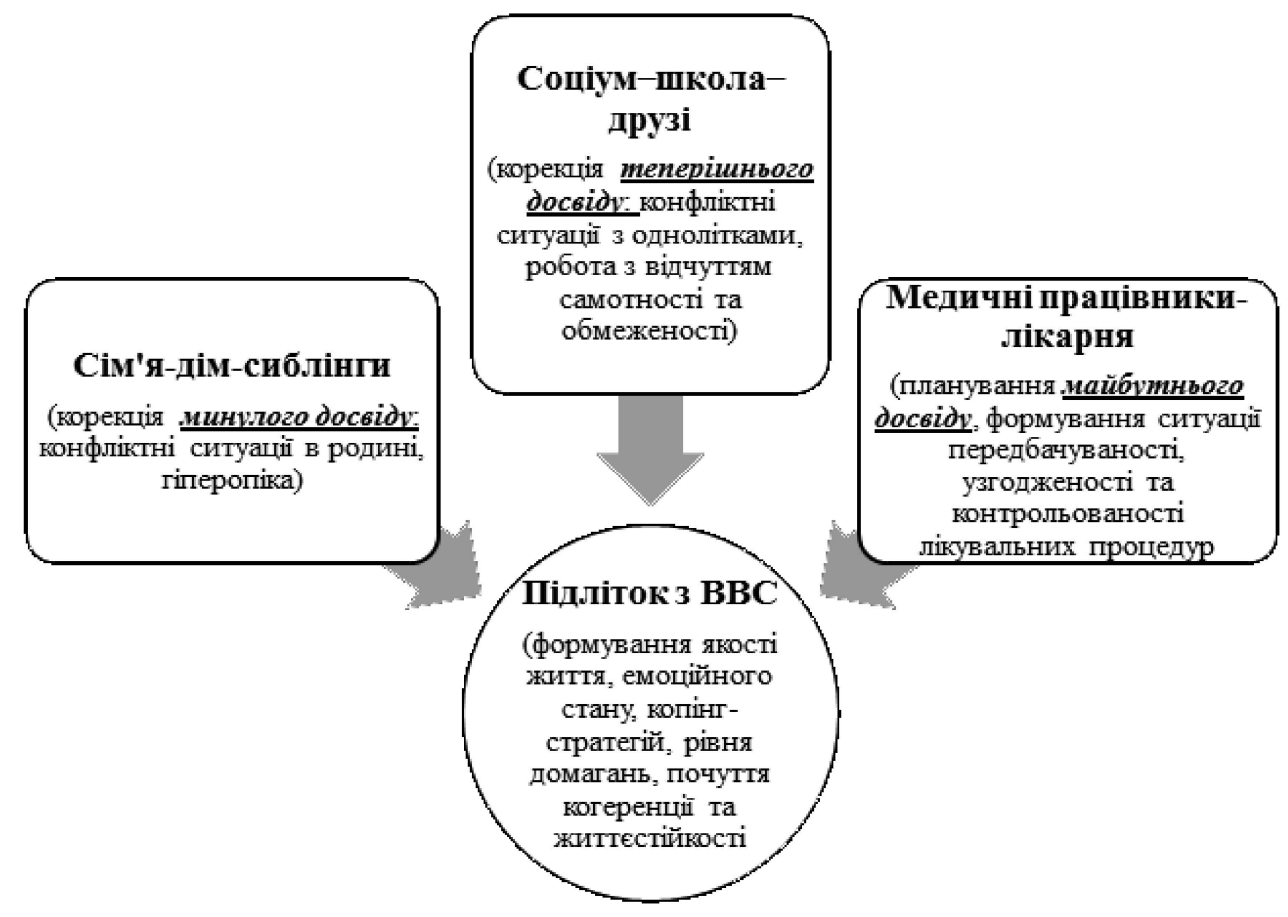

Рис. 1. Потенційно-корегована медичним психологом психосоціальна структура зовнішніх впливів на формування адаптаційного ресурсу підлітка з ВВС.

Психологу, кардіологу та батькам важливо сприяти розвитку у підлітків з ВВС такого компонента почуття когеренції як здатності керувати ситуацією. Під керованістю потрібно розуміти, що в цій ситуації підліток має можливість звернутись до лікуючого лікаря за необхідною інформацію, 
Огляди літератури, оригінальні дослідження, погляд на проблему

знає, як і що треба робити в стані загострення хвороби та має доступ до необхідних ресурсів (навчальні та освітні книги, буклети, веб-сайти, відеофільми). I знову ж таки, присутнє відчуття керованості не обов'язково означає, що підліток постійно звертається до лікаря або збирає додаткову інформацію, але він знає, що може покластися на батьків, друзів, медичних працівників та впоратися (інколи навіть просто витримати) зі своми медичними проблемами.

Також важливо оцінювати та сприяти розвитку у підлітка третього компонента почуття когеренції -усвідомленості. Під усвідомленістю можна розуміти емоційне переживання підлітка з ВВС того, що життя має сенс настільки, наскільки він відчуває, що проблеми та вимоги, які життя ставить перед ним, варті того, щоб активно включатися в них, Вкладати в них свої сили, що вони є викликами, які він приймає, а не намагається уникнути. На відміну від абсолютно когнітивної можливості осягнути проблему, емоційна усвідомленість пацієнта вказує на те, що медицина для нього не тільки складається 3 певних алгоритмів дій, але й $\epsilon$ небайдужою йому. Наприклад, якщо певні діагностично-лікувальні процедури не приносять фізичного полегшення та внутрішнього задоволення, підліток з розвинутим відчуттям емоційної усвідомленості розглядає їх як засіб або кроки, необхідні для реалізації наступних медичних цілей (профілактика ускладнень ВВС та подовження тривалості життя).

Таким чином, пацієнти з сильним почуттям когеренції будуть схильні розглядати потенційні стресові загрози як виклики, які ховають в собі нові можливості і, відповідно, варті того, щоб активно шукати шляхи до їх подолання, задіявши при цьому всі можливі ресурси. Такі пацієнти будуть більш відкриті до зворотного зв'язку, який даватиме можливість лікарю обрати нову стратегію діагностично-лікувальних процедур у разі невдачі. В кінцевому результаті сильне почуття когеренції сприятиме ефективному зняттю напруги та подоланню стресу, пов'язаного з хворобою.

Пацієнти ж зі слабким почуттям когеренції будуть закриватися, уникати проблем або переконувати себе у правильності обраної ними моделі поведінки.

Враховуючи думку А. Антоновського, що почуття когеренції формується в перші десятиріччя життя [14], важливо, щоб життєвий досвід підлітка з ВВС в лікарні характеризувався узгодженістю, тобто відсутністю обставин, які неможливо пояснити логічно, збалансованістю вимог, тобто коли завдання відповідають здібностям підлітка, адже нудьга та відчуття порожнечі, які можуть виникати при недостатньо високому рівні завдань, не менш небезпечні, ніж перенаванатаження пацієнта, та активною участю в прийнятті рішень, тобто коли способи розв'язання завдань пацієнтом з ВВС впливають на кінцевий результат лікування та реабілітації.

Висновки. Розроблена нами програма психологічної допомоги підліткам з ВВС виявилася ефективною. Впродовж дії програми вдалося знизити рівень підвищеної тривоги, усунути ознаки депресії під час стаціонарного лікування підлітків та закріпити ефект у віддаленому післяопераційному періоді, на етапі амбулаторного кардіологічного моніторингу. Також під час проходження програми вдалось сприяти посиленню розвитку у підлітків з ВВС почуття когеренції.

Якість життя підлітка з ВВС - це складний багатокомпонентний показник, який може бути скорегований медичним психологом не тільки шляхом безпосередньої роботи з пацієнтом з ВВС, але й через вплив на батьків та медичних працівників.

Перспективи подальших досліджень. В подальшому необхідно поширити та дослідити ефективність розробленої нами програми комплексної медико-психологічної допомоги на більшій кількості дітей з ВВС та їх батьків, модифікувавши їі з врахуванням віку дітей та тяжкості захворювання.

\section{ЛITEPATУPA}

1. What does it mean to live with a congenital heart disease? A qualitative study on the lived experiences of adult patients / P. Claessens, P. Moons, B. D. de Casterle, [et al.] // European journal of cardiovascular nursing. 2005. - № 4 (1). - P. 3-10.

2. Quality of life and congenital heart disease in childhood and adolescence / J. Bertoletti, G. C. Marx, S. P. Hattge, L. C. Pellanda // Arq. Bras. Cardiol. - 2014. № 102 (2). - P. 192-198.

3. Health-related quality of life outcomes in children and adolescents with congenital heart disease / K. Mellion, K. Uzark, A. Cassedy [et al.] // J. Pediatr. - 2014. - № 164 (4). - P. 781-788.
4. Quality of life of children with congenital heart diseases: a multicenter controlled cross-sectional study / P. Amedro, R. Dorka, S. Moniotte [et al.] // Pediatr. Cardiol. - 2015. - № 36 (8). - P. 1588-1601.

5. Associations between exercise capacity, physical activity, and psychosocial functioning in children with congenital heart disease: a systematic review / K. Dulfer, W. A. Helbing, N. Duppen, E. M. Utens // Eur. J. Prev. Cardiol. - 2014. - № 21 (10). - P. 1200-1215.

6. Growing up with congenital heart disease: The dilemmas of adolescents and young adults / E. M. Tong, P. S. A. Sparacino, D. K. H. Messias [et al.] // Cardiology in the young. -1998 . - № 8. - P. 303-309. 
Огляди літератури, оригінальні дослідження, погляд на проблему

7. A life less ordinary: growing up and coping with congenital heart disease / R. McMurray, L. Kendall, J. M. Parsons [et al.] // Coronary health care. - 2001. № 5. - P. 51-57.

8. Müller J. General anxiety of adolescents and adults with congenital heart disease is comparable with that in healthy controls / J. Müller, J. Hess, A. Hager // Int. J. Cardiol. - 2013. - № 165 (1). - P. 142-145.

9. A cohort study on psychosocial adjustment and psychopathology in adolescents and young adults with congenital heart disease / I. R. Freitas, M. Castro, S. L. Sarmento [et al.] // BMJ Open. - 2013. - № 3 (1):e001138. Available at: https://www.ncbi.nlm.nih.gov/pmc/articles/ PMC3563133/

10. The prevalence and predictors of anxiety and depression in adolescents with heart disease / Q. Wang, M. Hay, D. Clarke, S. Menahem // J. Pediatr. - 2012. - № 161 (5). - P. 943-946.

11. "It's No Big Deal": Adolescents With Congenital Heart Disease / K. Shearer, G. R. Rempel, C. M. Norris, J. Magill-Evans // Journal of pediatric nursing. - 2013. № 28. - P. 28-36.

12. Lee S. Coping and resilience of adolescents with congenital heart disease / S. Lee, S. Kim, J. Young Choi // J. Cardiovasc. Nurs. - 2014. - № 29 (4). - P. 340-346.

13. Sense of coherence is a predictor of perceived health in adolescents with congenital heart disease: a crosslagged prospective study / S. Apers, K. Luyckx, J. Rassart [et al.] // Int. J. Nurs. Stud. - 2013. - № 50 (6).- P. 776-785.

14. Antonovsky $A$. The sense of coherence as a determinant of health / A. Antonovsky // Advances,

Institute for Advancement of Health. - 1984. - № 1 (3). P. 37-50.

15. Осин Е. Н. Чувство связности как показатель психологического здоровья и его диагностика / Е. Н. Осин // Психологическая диагностика. - 2007. № 3. - С. 22-40.

16. Мадди С. Смыслообразование в процессах принятия решения / С. Мадди // Психологический журнал. -2005 . - Т. 26, № 6. - С. 87-101.

17. Associations between knowledge of disease, depression and anxiety, social support, sense of coherence and optimism with health-related quality of life in an ambulatory sample of adolescents with heart disease / Q. Wang, M. Hay, D. Clarke, S. Menahem // Cardiol. Young. -2014. - № 24 (1). - P. 126-133.

18. A big five personality typology in adolescents with congenital heart disease: prospective associations with psychosocial functioning and perceived health / J. Rassart, K. Luyckx, E. Goossens [et al.] // Int. J. Behav. Med. - 2016. - № 23 (3). - P. 310-318.

19. Уніфікований клінічний протокол первинної, вторинної (спеціалізованої) та третинної (високоспеціалізованої допомоги). Депресії. Від 25 грудня 2014 року № 1003. Доступний: http://moz.gov.ua/docfiles/ dn_20141225_1003dod.pdf

20. Koposov R. A. Sense of coherence: a mediator violence exposure and psychopathology in russian juvenile delinquents / R. A. Koposov, V. V. Ruchkin, M. Eisenmann // The J. of Nervous and Mental Disease. - 2003. - № 191 (10). - P. 638-644.

\title{
THE PROGRAM OF PSYCHOLOGICAL ASSISTANCE FOR ADOLESCENTS WITH CONGENITAL HEART DISEASE
}

\author{
@A. Yu. Sydorenko \\ Scientific and Practical Medical Centre of Pediatric Cardiology and Cardiosurgery of Ministry of Healthcare of \\ Ukraine, Kyiv
}

SUMMARY. The scheme and principles of psychological assistance for adolescents with congenital heart disease $(\mathrm{CHD})$ is presented in the article. 25 adolescents aged 13-15 years with a high level of anxiety, depression and a weak sense of coherence took part in the study. Psychological measures covered from 5 to 10 individual consultations with CHD teenagers and separately with parents. The program of psychocorrection consisted of elements of rational and cognitive-behavioral therapy, analysis of complex life and clinical situations (cases), autogenous training and elements of cardio- and psychoeducation. The program was effective for all adolescents with CHD. We managed to normalize the adolescents' level of anxiety and eliminate in vast majority of them the signs of depression. In addition, within six months we managed to further develop and enhance a sense of coherence among CHD adolescents.

KEY WORDS: adolescents, congenital heart disease, psychological assistance. 